\title{
Conditions and challenges
}

\section{Debates on Democratization \\ edited by Larry Diamond, \\ Marc E. Plattner, and \\ Philip J. Costopoulos}

As a service to students and teachers who wish to deepen their understanding of the questions and controversies that surround contemporary democratization, the Journal of Democracy has now brought together a series of exchanges on the topic.

$A$ Journal of Democracy Book $\$ 25.00$ paperback

\section{Plato's Political Philosophy Mark Blitz}

"An extraordinarily fresh, rich, and thoughtprovoking introduction to Plato's political philosophy. Blitz takes a synoptic approach, combining in-depth textual analysis of particular dialogues with illuminating thematic discussions."

—Peter J. Ahrensdorf, Davidson College

\$24.95 paperback

\section{Latin America and Global Capitalism \\ A Critical Globalization Perspective William I. Robinson \\ Book Prize, International Political Economy Group, British International Studies Association \\ "Robinson's latest book offers brilliant insight into the underlying causes and current dilem- mas of globalization." and Robert Aronowitz \\ "Scholars and policymakers alike will draw lasting lessons from this timely, fascinating, and engaging collection on the controversial HPV vaccine." \\ —Elizabeth Mitchell Armstrong, Princeton University \\ $\$ 30.00$ paperback}

- NACLA Report on the Americas Johns Hopkins Studies in Globalization: Christopher Chase-Dunn, Series Editor \$35.00 paperback

\section{The European Union and Democracy Promotion A Critical Global Assessment edited by Richard Youngs}

"A rare cross-regional analysis, this book is a potentially important corrective to the dominant view of EU foreign policy in the area of democracy promotion." -Lucan A. Way, University of Toronto Democratic Transition and Consolidation: Jorge I. Dominguez and Anthony Jones, Series Editors $\$ 60.00$ hardcover
The Politics of Judicial Independence Courts, Politics, and the Public edited by Bruce Peabody

"This edited volume of essays on the relations between courts (primarily the U.S. Supreme Court) and other branches of government documents and analyzes a remarkable political jousting that has ebbed and flowed throughout the nation's history. It is a demonstration of the power of political science to reveal rarely acknowledged realities of the judicial process in a democratic society." —Richard A. Posner, Judge, United States Court of Appeals for the Seventh Circuit, and Senior Lecturer at the University of Chicago Law School $\$ 28.00$ paperback

\section{Three Shots at Prevention The HPV Vaccine and the Politics of Medicine's Simple Solutions edited by Keith Wailoo, Julie Livingston, Steven Epstein,}

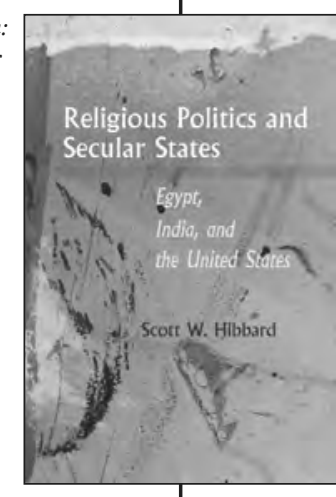

\section{Religious Politics and} Secular States

Egypt, India, and the

United States

Scott W. Hibbard

"No one has shown so comprehensively as Scott Hibbard the impact of the political manipulation of religion on shaping national ideals. His examination of the contemporaneous policies of the Indian, Egyptian, and American governments is as revealing as it is original." —David Little, Harvard Divinity School $\$ 60.00$ hardcover

\section{Crafting State-Nations}

India and Other Multinational Democracies Alfred Stepan, Juan J. Linz, and Yogendra Yadav

"Remarkably erudite and conceptually innovative, Crafting State-Nations will reconfigure the debate on nations and nationalism, and on the relationship between national diversity and political institutions. The authors have brilliantly succeeded in expanding our political imaginations."

—Ashutosh Varshney, Brown University $\$ 30.00$ paperback

\section{WOODROW WILSON CENTER PRESS}

\section{0}

\section{Policing Democracy \\ Overcoming Obstacles to Citizen Security in Latin America \\ Mark Ungar \\ "Very few scholars in the field have the grasp of recent changes in and problems of systems of citizen security in Latin America that this author has. His vision is comprehensive, extending from policing to the judiciary to the prison system."-Anthony W. Pereira, Tulane University \$30.00 paperback}

\section{Urban Diversity}

Space, Culture, and Inclusive Pluralism in Cities Worldwide

edited by Caroline Wanjiku Kihato, Meigan Massoumi, Blair A. Ruble, Pep Subirós, and Allison M. Garland

"The book is original in its global comparative perspective. It captures the global problem of the ever-increasing size of cities and hence their sustainability." - Caroline B. Brettell, Southern Methodist University $\$ 65.00$ hardcover

\section{Orange Revolution and Aftermath} Mobilization, Apathy, and the State in Ukraine edited by Paul D'Anieri

"This book takes a step back from the immediate events and asks some important and interesting questions about the state of Ukrainian democracy and society today." —Paul Kubicek, Oakland University $\$ 60.00$ hardcover 


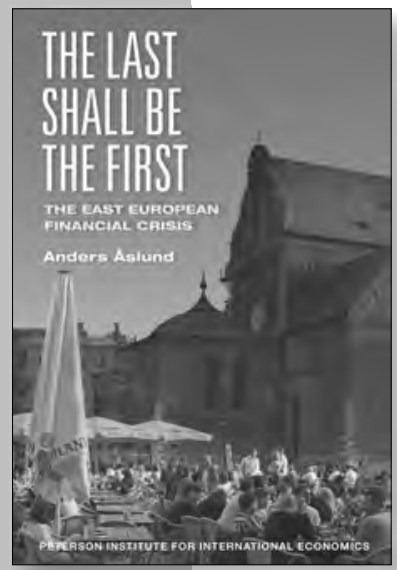

\section{The Last Shall Be the First}

The East European Financial Crisis

Anders Åslund

$\$ 21.95$

\section{The Implications of China-Taiwan Economic Liberalization}

Daniel Rosen \& Zhi Wang $\$ 21.95$

\section{Russia After the Global Economic Crisis}

Anders Åslund, Sergei Guriev \& Andrew Kuchins, editors $\$ 22.95$

\section{Witness to Transformation}

Refugee Insights into North Korea

Stephan Haggard \& Marcus Noland $\$ 23.95$

\section{The World After the Financial Crisis}

Simon Johnson \& Arvind Subramanian $\$ 18.95$

\section{Figuring Out the Doha Round}

Gary Clyde Hufbauer, Jeffrey J. Schott \& Woan Foong Wong $\$ 19.95$ 


\section{KANSAS}
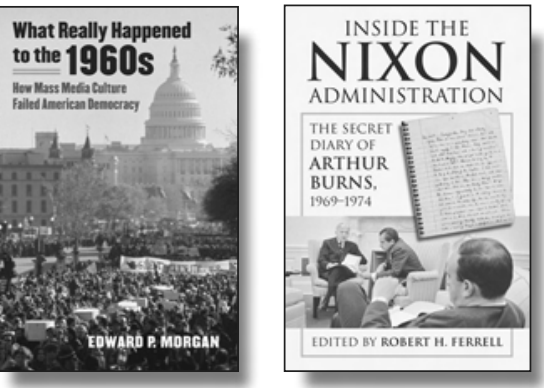

\section{What Really Happened to the 1960s}

How Mass Media Culture Failed American Democracy

Edward P. Morgan

"This important book provides an illuminating historical overview, critical analysis, and appraisal of the 1960s. Drawing upon historical and media studies, theories of capitalism and democracy, and in-depth study of the era's social movements, Morgan provides an extremely comprehensive and penetrating analysis of the events and aftermath of the 1960s."-Douglas Kellner, author of Media Spectacle and the Crisis of Democracy and Media Culture 456 pages, 35 photographs, Cloth $\$ 39.95$
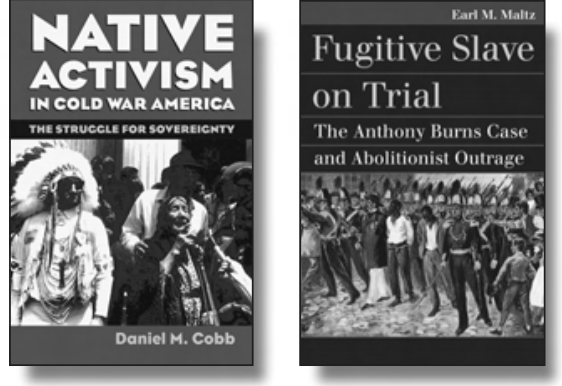

\section{Inside the Nixon Administration}

The Secret Diary of Arthur Burns, 1969-1974

Edited by Robert H. Ferrell

"Provides invaluable insights into the inner workings of the Nixon administration, the economic issues it confronted, and the fascinating and strange character of Nixon himself."-Wyatt C. Wells, author of Economist in an Uncertain World: Arthur F. Burns and the Federal Reserve, 1970-78

"Will amaze and enthrall anyone who wants to know what the Federal Reserve has done to our money."-James Grant, editor, Grant's Interest Rate Observer 144 pages, 14 photos, Cloth $\$ 24.95$
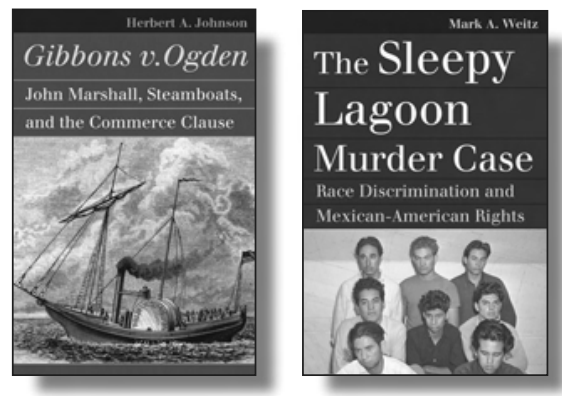

NEW IN PAPERBACK

Native Activism in Cold War America The Struggle for Sovereignty

Daniel M. Cobb

"An impressive and significant achievement, Cobb's engaging chronicle makes an original and important contribution to the literature on American Indian political activism, federal Indian policy, LBJ's War on Poverty, and post-1945 U.S. politics.' -Alice O'Connor, author of Poverty Knowledge: Social Science, Social Policy, and the Poor in Twentieth-Century U.S. History

318 pages, 33 illustrations, 1 map, Paper $\$ 19.95$

\section{Landmark Law Cases and American Society}

Peter Charles Hoffer and N.E.H. Hull, series editors

\section{Fugitive Slave on Trial}

The Anthony Burns Case and Abolitionist Outrage

Earl M. Maltz

"Innovative, fresh, and provocative, this well-crafted page turner centers on the trial of Anthony Burns, whose status as slave or freedman was in great dispute. Filled with colorful characters and a twisting plot worthy of Agatha Christie, it pushes well beyond the fate of Burns himself to cover the vehement backlash against trial judge Edward Loring, who was forced to leave the bench."- Sally Hadden, author of Slave Patrols: Law and Violence in Virginia and the Carolinas

192 pages, Cloth $\$ 34.95$, Paper $\$ 17.95$

\section{Gibbons v. Ogden}

John Marshall, Steamboats, and the Commerce Clause

Herbert A. Johnson

"A learned but accessible, eloquent, and engaging study that displays Johnson's encyclopedic knowledge. It is necessary reading for anyone interested in how the court understands and applies one of the most important provisions in the Constitution."-Mark R. Killenbeck, author of M'Culloch v. Maryland: Securing a Nation

216 pages, Cloth $\$ 34.95$, Paper $\$ 17.95$

\section{The Sleepy Lagoon Murder Case}

Race Discrimination and Mexican-American Rights

Mark A. Weitz

"Weitz brings to the case a keen understanding of law and courtroom dynamics, helping readers to understand more completely its importance for legal history. Looking at it from this perspective is entirely new and is an important contribution."-Eduardo Obregón Pagán, author of Murder at the Sleepy Lagoon: Zoot Suits, Race, and Riot in Wartime L.A. 232 pages, Cloth $\$ 34.95$, Paper $\$ 17.95$ 

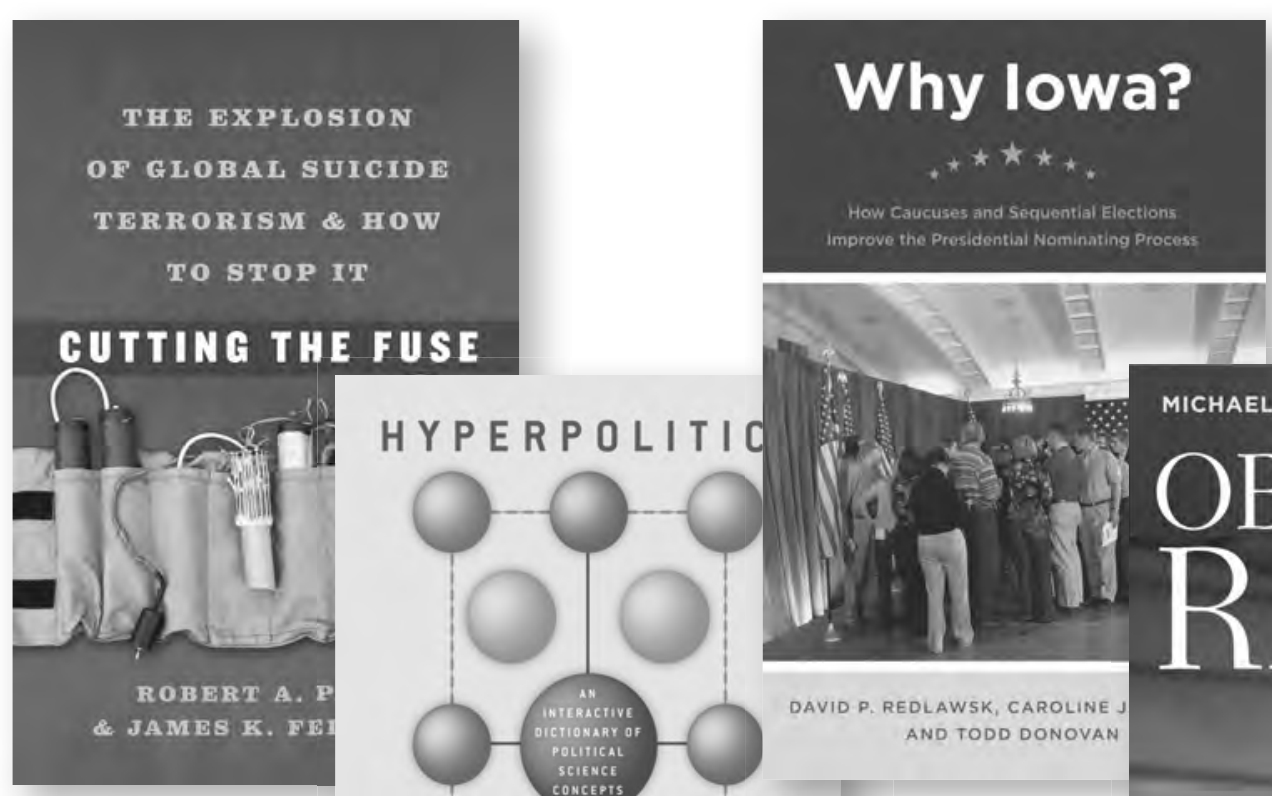

\section{from Chicago}

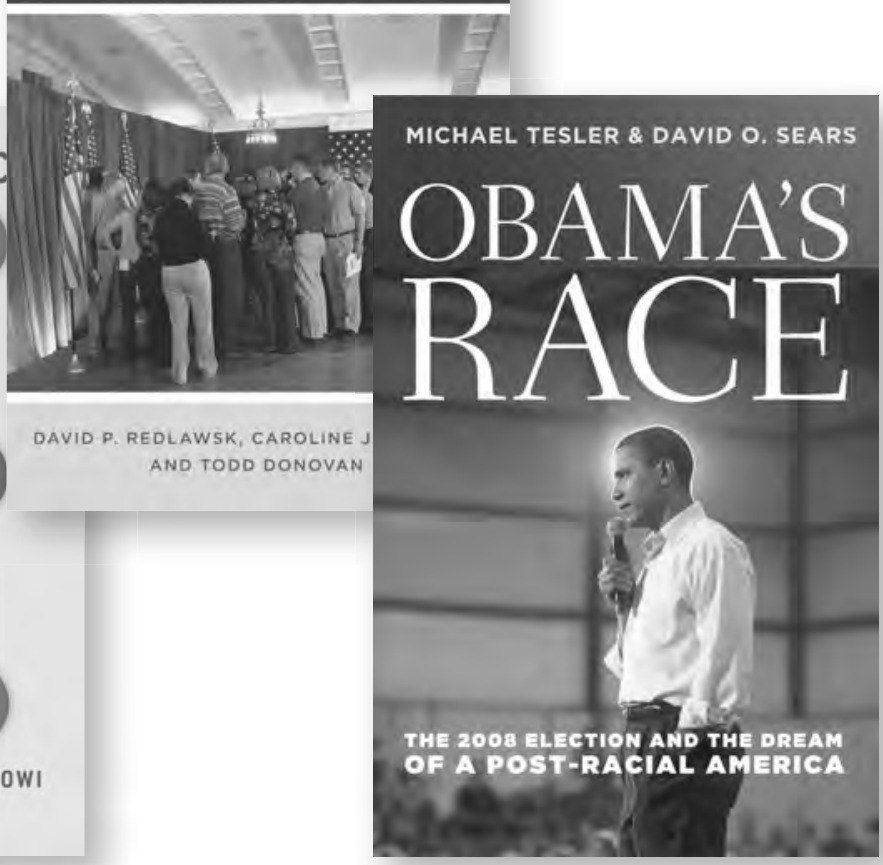

\section{Cutting the Fuse}

The Explosion of Global Suicide Terrorism and How to Stop It

Robert A. Pape and James K. Feldman

Cloth $\$ 30.00$

\section{World Rule}

Accountability, Legitimacy, and the Design of Global Governance Jonathan GS Koppell Paper $\$ 36.00$

\section{Specializing the Courts}

Lawrence Baum

Paper $\$ 27.50$

H Y P E R P O LIT I C

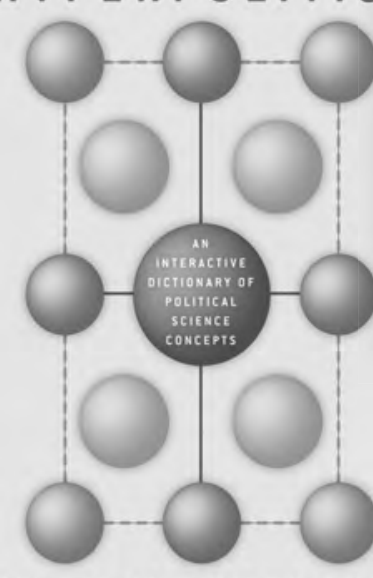

MAURO CALISE \& THEODORE J. LOW

\section{Hyperpolitics}

An Interactive Dictionary of Political Science Concepts

Mauro Calise and

Theodore J. Lowi

Paper $\$ 18.00$

\section{Strengthening Peace in Post-Civil War States}

Transforming Spoilers into Stakeholders

Edited by Matthew Hoddie and Caroline A. Hartzell

Paper $\$ 29.00$

\section{After the Rubicon}

Congress, Presidents, and the Politics of Waging War

Douglas L. Kriner

Paper $\$ 30.00$

\section{Why lowa?}

How Caucuses and Sequential Elections Improve the Presidential Nominating Process David P. Redlawsk, Caroline J. Tolbert, and Todd Donovan

Paper $\$ 27.50$

\section{Now in Paperback}

News That Matters

Television and American Opinion, Updated Edition Shanto lyengar and Donald R. Kinder Paper $\$ 17.00$

\section{Obama's Race}

The 2008 Election and the Dream of a Post-Racial America

Michael Tesler and

David 0. Sears

Paper $\$ 18.00$

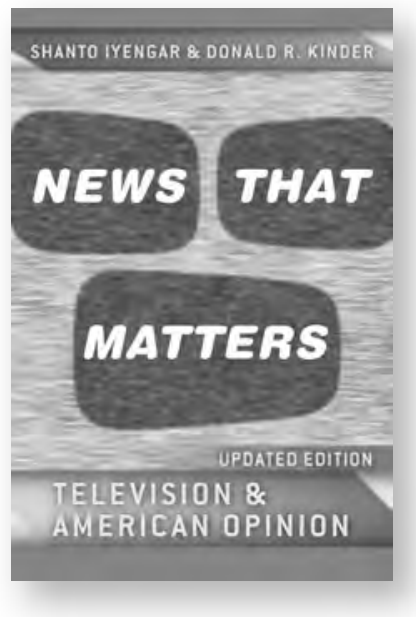




\section{GREAT IDEAS}

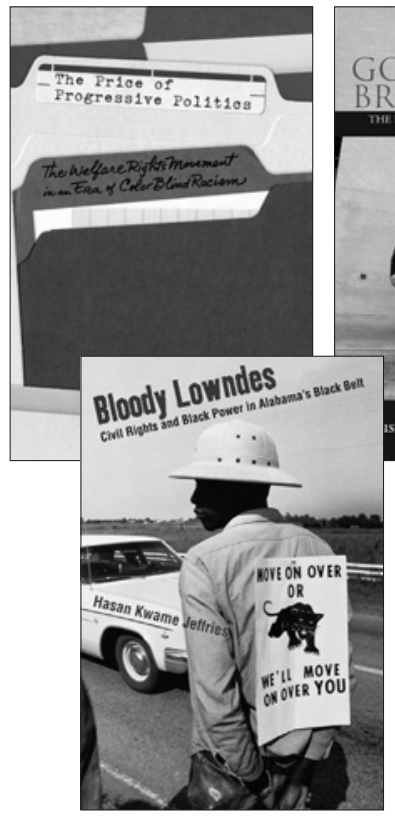

The Price of

\section{Progressive Politics}

The Welfare Rights Movement

in an Era of Colorblind Racism

ROSE ERNST

$\$ 22.00$ paper $>6$ figures, 10 tables

\section{When Governments Break the Law}

The Role of Law and the Prosecution of the Bush Administration

AUSTIN SARAT and

NASSER HUSSAIN

$\$ 25.00$ paper

NEW IN PAPERBACK!

\section{Bloody Lowndes}

Civil Rights and Black Power in

Alabama's Black Belt

HASAN KWAME JEFFRIES

$\$ 22.00$ paper $>23$ illustrations
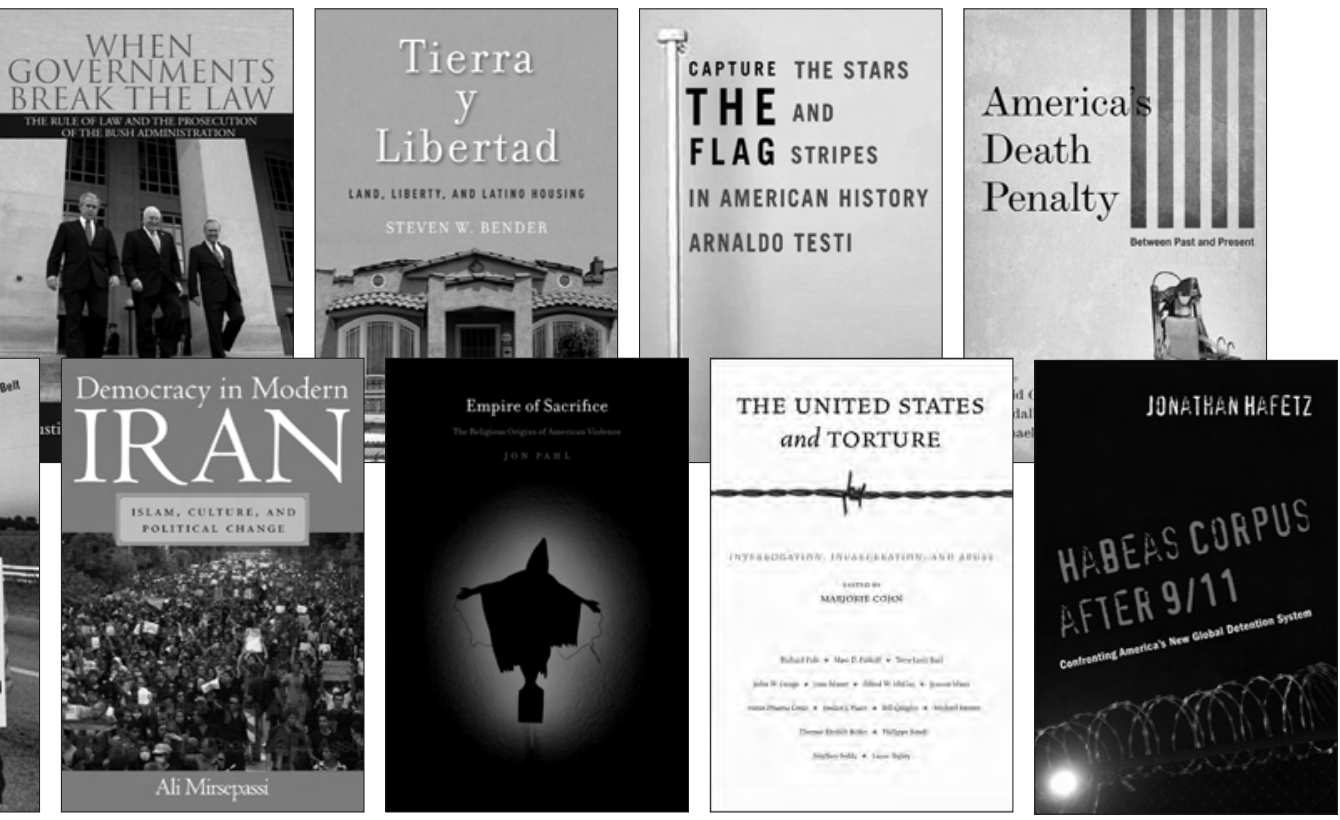

Tierra Y Libertad

Land, Liberty, and Latino Housing

STEVEN W. BENDER

$\$ 39.00$ cloth $>$ I table

Citizenship and Migration in the Americas Series

\section{Democracy in Modern Iran}

Islam, Culture, and Political Change

ALI MIRSEPASSI

$\$ 42.00$ cloth

\section{Capture the Flag}

The Stars and Stripes in American History

ARNALDO TESTI

$\$ 22.95$ cloth > 28 illustrations

\section{Empire of Sacrifice}

The Religious Origins of American Violence

JON PAHL

$\$ 35.00$ cloth > 2 illustrations

\section{FORTHCOMING}

\section{America's Death Penalty}

Between Past and Present

DAVID GARLAND,

RANDALL MGGOWEN, and

MICHAEL MERANZE

$\$ 22.00$ paper $>6$ figures

Available January 2011

\section{United States and Torture}

Interrogation, Incarceration, and Abuse

MARJORIE GOHN

$\$ 39.00$ cloth $>$ no illustrations

Available January 2011

\section{Habeas Corpus After 9/11}

JONATHAN HAFETZ

$\$ 39.00$ cloth

Available January 2011

\section{Radicalism at the \\ Crossroads}

African American Women Activists

in the Cold War

DAYO F. GORE

$\$ 39.00$ cloth $>7$ illustrations

Available February 2011 


\section{The MIT Press}

\section{Laws, Outlaws, and Terrorists}

LESSONS FROM THE WAR ON TERRORISM

Gabriella Blum and Philip B. Heymann

"This is an excellent work, with highly creative proposals and sensitive analysis. The most important task in the wars on terror will be the mutual adaptation of strategy and law in order to provide a legitimate basis on which such wars can be fought. It is to this end that Heymann and Blum have made a major contribution."

— Philip Bobbitt, Columbia Law School, and University of Texas

Belfer Center Studies in International Security 232 pp., \$21.95 cloth

\section{Knowledge and Environmental Policy}

RE-IMAGINING THE BOUNDARIES OF SCIENCE AND POLITICS

William Ascher, Toddi Steelman, and Robert Healy

"This book is a lucid, concise, yet comprehensive primer on how environmental science and policy interact in the governing process and how that interaction can be improved." - Walter A. Rosenbaum, University of Florida American and Comparative Environmental Policy series $280 \mathrm{pp}$. , \$23 paper

\section{The Environmental Politics of Sacrifice}

edited by Michael Maniates and John M. Meyer

"This is an excellent, thoughtful, and original book. I came to the material skeptically and came away from it convinced that this is indeed an important area to explore, and that much more can be made of the idea of sacrifice than would generally be assumed." - Andrew Dobson, Keele University $344 \mathrm{pp}$. , \$25 paper

\section{Institutional Dynamics}

EMERGENT PATTERNS IN INTERNATIONAL ENVIRONMENTAL GOVERNANCE

\section{Oran R. Young}

"This book breaks new ground in analyzing the dynamics of change in environmental institutions, while offering the same impressive theoretical creativity, conceptual precision, and broad learning that we expect from the work of Oran Young. It is a valuable piece of work, and I expect to make use of it in both my research and teaching." - Edward A. Parson, University of Michigan

Earth System Governance series • 232 pp., 3 illus., \$24 paper

\section{Immigrants and the Right to Stay}

Joseph H. Carens

A proposal that immigrants in the United States should be offered a path to legalized status.

A Boston Review Book • 128 pp., \$14.95 cloth

\section{The Minimum Wage and Labor Market Outcomes} Christopher J. Flinn

"One of the more intriguing undercurrents in minimum wage research over the last two decades has been the reevaluation of the predicted effects of minimum wages in labor market models characterized by search frictions, rather than the standard competitive model. Flinn does an outstanding job both synthesizing this technically difficult literature and showing how the search framework can be used to evaluate not only the employment effects of minimum wages but also their welfare implications. An invaluable contribution to the research literature on minimum wages and on job search models more generally."

- David Neumark, University of California, Irvine

344 pp., 15 illus., $\$ 40$ cloth

\section{America Identified}

BIOMETRIC TECHNOLOGY AND SOCIETY

\section{Lisa S. Nelson}

"Biometric identification in all its forms is becoming increasingly important to our brave new world of constant surveillance. In this highly approachable, wonderfully insightful book, Lisa Nelson walks us though an issue that should be of concern to policy makers, science studies scholars, and indeed all citizens."

— Geoffrey C. Bowker, University of Pittsburgh 200 pp., 26 illus., $\$ 32$ cloth

\section{Networks and States \\ THE GLOBAL POLITICS OF INTERNET GOVERNANCE}

\section{Milton L. Mueller}

How institutions for Internet governance are emerging from the tension between the territorially bound nation-state and a transnational network society.

Information Revolution and Global Politics series

280 pp., 7 illus., $\$ 35$ cloth

\section{Contending with Terrorism} ROOTS, STRATEGIES, AND RESPONSES

\section{edited by Michael E. Brown}

Owen R. Coté Jr., Sean M. Lynn-Jones, and Steven E. Mille

Experts explore the sources of contemporary terrorism, what terrorists want, and how the United States and other countries should respond.

An International Security Reader • 464 pp., \$28 paper

\section{Global Commons, Domestic Decisions}

THE COMPARATIVE POLITICS OF CLIMATE CHANGE

edited by Kathryn Harrison and Lisa McIntosh Sundstrom

"This book makes an important and distinctive contribution to the literature on comparative environmental policies and politics. It clearly and convincingly describes and explains the policy approaches of the European Union, the United States, Russia, Japan, Canada, Australia, and China toward addressing the risks of global climate change. I highly recommend it to anyone interested in understanding the complex relationship between the domestic and international dimensions of climate change policies." - David Vogel, University of California, Berkeley

American and Comparative Environmental Policy series 320 pp., 2 illus., \$25 paper

\section{New in Paper}

\section{The Privacy Advocates}

\section{RESISTING THE SPREAD OF SURVEILLANCE}

\section{Colin J. Bennett}

"The Privacy Advocates will become one of the essential books for understanding privacy issues in this decade." - Privacy Journal

268 pp., 11 illus., \$14 paper

\section{NE BOOKS}

Walled States, Waning Sovereignty Wendy Brown Why do nation-states wall themselves off despite widespread proclamations of global connectedness?

Distributed for Zone Books • 168 pp., 7 illus., \$25.95 cloth 


\section{CORNELL UNIVERSITY PRESS}
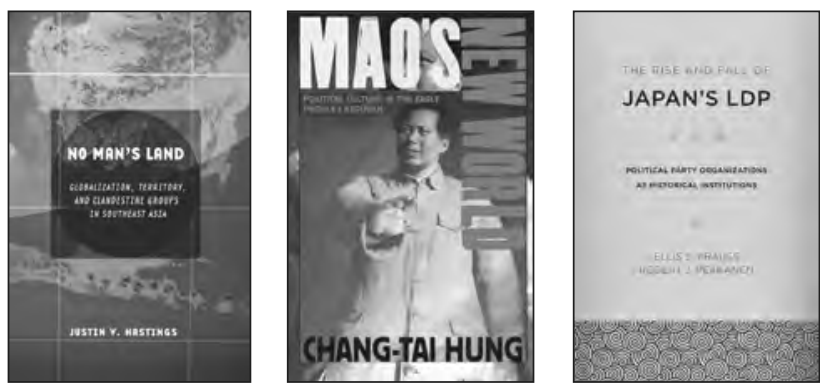

\section{PRIVATIZING WATER}

Governance Failure and the World's Urban Water Crisis

KaRen BAKKer

"Bakker's Privatizing Water bravely and provocatively takes on the state and private models for governing urban water and proposes a radical and deeply illuminating rethinking of keywords such as public, community, and the market."

- Michael Watts, UC Berkeley

[\$24.95 paper ]

\section{PUBLIC LAW AND PRIVATE POWER}

Corporate Governance Reform in the Age of Finance Capitalism John W. CIOFFI

"By comparing the superimportant economies of Germany and the United States, Cioffi provides great value."

- Peter A. Gourevitch, UC San Diego

[\$39.95 cloth | Cornell Studies in Political Economy ]

\section{CULTURES AT WAR}

The Cold War and Cultural Expression in Southeast Asia

Edited by Tony Day and Maya H. T. Liem

"These innovative essays compel us to reevaluate our understanding of the Cold War as a predominantly political and military event."

-Richard A. Ruth, United States Naval Academy

[\$25.95 paper | Distributed for Southeast Asia Program Publications ]

\section{LOCATING MIGRATION}

Rescaling Cities and Migrants

Edited by Nina Glick Schiller and Ayşe Çă̆lar

"Locating Migration is an excellent collective work showing how the particularities of cities collide with the dreams and aspirations of international migrants to shape varying paths to integration.

- Leo R. Chavez, author of The Latino Threat [\$29.95 paper]

\section{NO MAN'S LAND}

Globalization, Territory, and Clandestine Groups in Southeast Asia Justin V. HASTINGS

"Engaging and accessible, No Man's Land is a fascinating book on extremely timely and important topics-terrorism, insurgency, and cross-border crime."-Peter ANDREAs, Brown UNIVERSITy [\$22.95 paper ]

\section{MIRRORS OF THE ECONOMY}

National Accounts and International Norms in Russia and Beyond

YoSHIKO M. HERRERA

"Mirrors of the Economy offers original insights into the interaction of domestic and international factors producing major institutional change."-Matthew Evangelista, Cornell University [\$49.95 cloth | Cornell Studies in Political Economy]

\section{MAO'S NEW WORLD}

Political Culture in the Early People's Republic

Chang-tal Hung

"Hung provides an expansive, panoramic view of the first decade of the People's Republic that makes clear the central place of the arts in the Party's political strategy."-Richard KraUs, University OF OREgON [\$39.95 cloth ]

\section{THE RISE AND FALL OF JAPAN'S LDP}

Political Party Organizations as Historical Institutions

Ellis S. Krauss and Robert J. Pekkanen

"This is, in my view, the best book ever written on Japan's Liberal Democratic Party (LDP).”-EThan Scheiner, UC Davis [\$26.95 paper]

\section{New in Paperback}

\section{CHINA'S WATER WARRIORS}

\section{Citizen Action and Policy Change}

Andrew C. Mertha

"Addressing the role of forces outside the government in China's policymaking, Mertha's China's Water Warriors makes a significant and insightful contribution."-POLITICAL SCIENCE QUARTERLY [\$21.00 paper ]

\section{WEAPONS OF THE WEALTHY}

Predatory Regimes and Elite-Led Protests in Central Asia Scott RAdNITZ

"In this book Radnitz provides an elegant theory of 'subversive clientelism' that explains how vertical and horizontal networks of patronage actually operate."

-Alexander Cooley, Columbia University [\$35.00 cloth ]

\section{New in Paperback}

\section{REGULATING CAPITAL}

Setting Standards for the International Financial System

David Andrew Singer

"Singer offers a refreshing approach to the analysis of regulatory issues in international financial markets."- СНОICE [\$21.00 paper | Cornell Studies In Money ]

\section{THE MILITARY LENS}

Doctrinal Difference and Deterrence Failure in Sino-American Relations

Christopher P. Twomey

"Twomey clarifies the central importance of military doctrines in shaping the outcomes that result when states rely on threats to pursue their international interests."

- Avery Goldstein, University of Pennsylvania [\$35.00 cloth | Cornell Studies in Security Affairs ] 


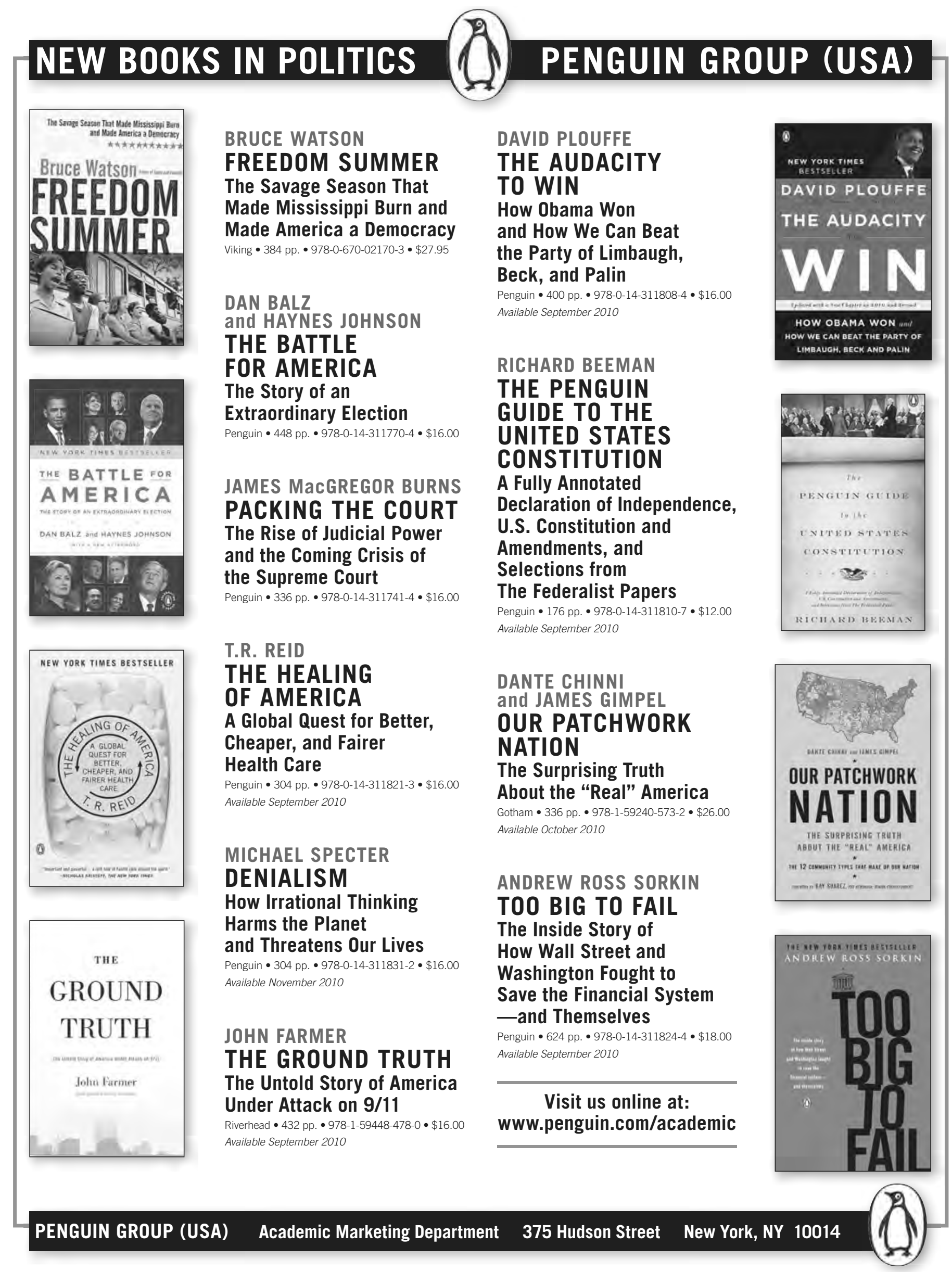




\section{NEW in Politics and International Relations...}

\section{America's War on Terror}

Edited by Tom Lansford, Robert P. Watson and Jack Covarrubias

SECOND EDITION

"... a significant contribution..."

-Chris J. Dolan, Lebanon Valley College October 2009. 386 pgs. Hbk. 978-0-7546-7785-7 Pbk. 978-0-7546-7787-1. eBk. 978-0-7546-9533-2

\section{The Ashgate Research Companion} to New Public Management

Edited by Tom Christensen and Per Lægreid

"A must collection for anyone interested in contemporary administrative reform."

—Joel D. Aberbach, University of California,

January 2011. 528 pgs. Hbk. 978-0-7546-7806-9 Los Angeles eBk. 978-0-7546-9570-7

The Ashgate Research Companion to Non-State Actors

Edited by Bob Reinalda

"...A sophisticated addition to the topic..."

-Karen Mingst, University of Kentucky

March 2011. 592 pgs. Hbk. 978-0-7546-7906-6

eBk. 978-0-7546-9794-7

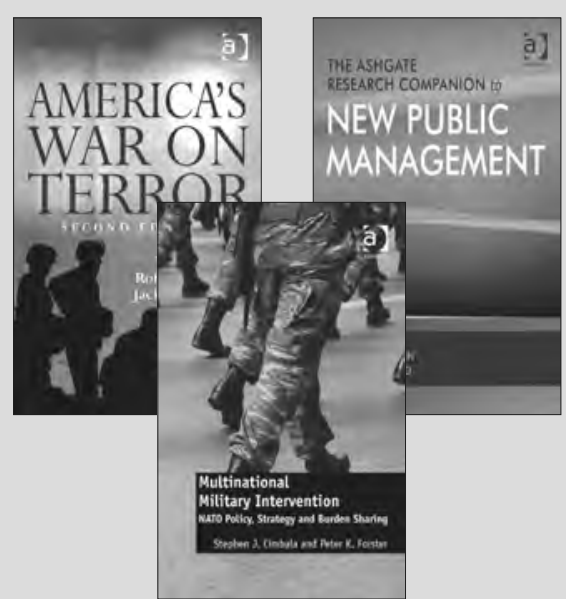

The Euro in the 21st Century

Economic Crisis and Financial Uproar

Maria Lorca-Susino

THE INTERNATIONAL POLITICAL ECONOMY

of NEW REGIONALISMS SERIES

"The topic of this book could not be more timely..." -David Stasavage, New York University

January 2011. 282 pgs. Hbk. 978-1-4094-0418-7

eBk. 978-1-4094-0419-4

\section{EU Counterterrorism Policy}

A Paper Tiger?

Oldrich Bures

"...a must-read..."

-Christoph O. Meyer, King's College London, UK March 2011. 262 pgs. Hbk. 978-1-4094-1123-9

eBk. 978-1-4094-1124-6

\section{Multinational Military Intervention}

NATO Policy, Strategy and Burden Sharing

Stephen J. Cimbala and Peter K. Forster

"...An invaluable book..."

—Martin A. Smith, Royal Military Academy

April 2010. 254 pgs. Hbk. 978-1-4094-0228-2 Sandhurst, UK

eBk. 978-1-4094-0229-9

\section{Securing the Global Economy}

G8 Global Governance for a Post-Crisis World Edited by Andreas Freytag, John J. Kirton, Razeen Sally and Paolo Savona

GLOBAL FINANCE

"...The book is highly recommended."

—Friedrich Schneider, Johannes Kepler University of Linz, Austria

March 2011. 212 pgs. Hbk. 978-0-7546-7673-7

eBk. 978-0-7546-7674-4

Toll-free: 1-800-535-9544•Email: orders@ashgate.com • All online orders receive a discount • www.ashgate.com 


\section{New from BROOKINGS}

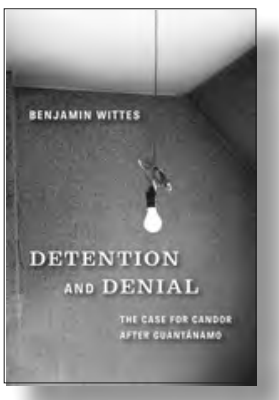

Benjamin Wittes

$150 \mathrm{pp}$.

cloth, 978-0-8157-0491-1, \$22.95

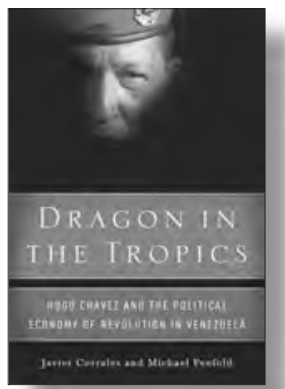

Dragon in the Tropics

Detention and Denial The Case for Candor after Guantánamo

J avier Corrales and Michael Penfold

$175 \mathrm{pp}$.

paper, 978-0-8157-0497-3, \$22.95

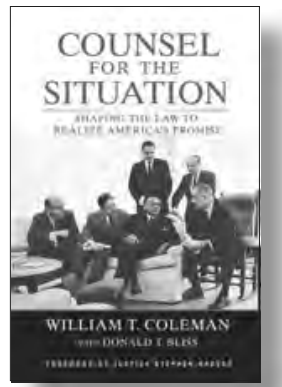

Counsel for the Situation Shaping the Law to Realize America's Promise

William T. Coleman J r. with Donald T. Bliss

$466 \mathrm{pp}$.

cloth, 978-0-8157-0488-1, \$34.95

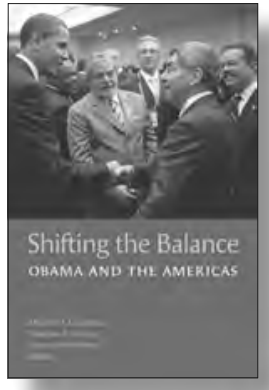

Shifting the Balance Obama and the Americas

Abraham F. Lowenthal, Theodore Piccone, and Laurence Whitehead, eds. 170 pp.,

paper, 978-0-8157-0562-8, \$24.95

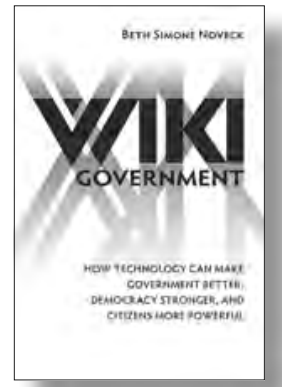

New in paperback Wiki Government How Technology Can Make Government Better, Democracy Stronger, and Citizens More Powerful

\section{Beth Simone Noveck}

$224 \mathrm{pp}$.

paper, 978-0-8157-0510-9, \$19.95

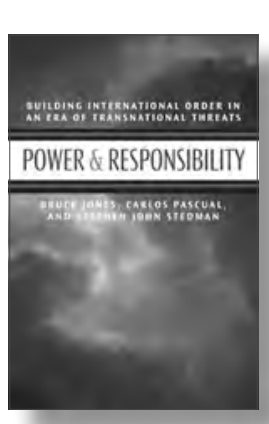

New in paperback Power and Responsibility Building International Order in an Era of Transnational Threats

Bruce J ones, Carlos Pascual, and Stephen J ohn Stedman $360 \mathrm{pp}$.

paper, 978-0-8157-0512-3, \$24.95

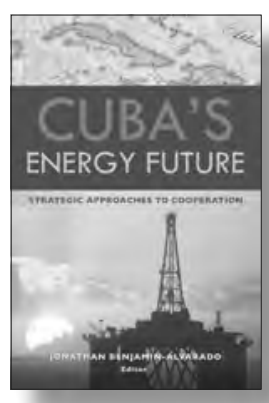

Cuba's Energy Future Strategic Approaches to Cooperation

J onathan Benjamin-Alvarado, ed. $143 \mathrm{pp}$.

paper, 978-0-8157-0342-6, \$26.95

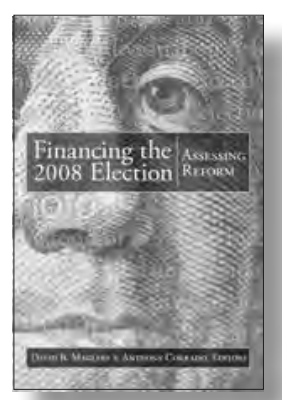

Financing the 2008 Election Assessing Reform

David B. Magleby and Anthony Corrado, eds. $240 \mathrm{pp}$. paper, 978-0-8157-0332-7, \$29.95 


\section{What's New in Political Science?}

\section{Cambridge Studies in Comparative Politics}

Immigration and

Conflict in Europe

Rafaela M. Dancygier

\$90.00: Hb: 978-0-521-19907-0: $352 \mathrm{pp}$. \$28.99: Pb: 978-0-521-15023-1

Post-Imperial Democracies Ideology and Party Formation in Third Republic France, Weimar Germany, and Post-Soviet Russia Stephen E. Hanson \$90.00: Hb: 978-0-521-88351-1: 306 pp. \$26.99: Pb: 978-0-521-70985-9

Evolution, Creationism, and the Battle to Control America's Classrooms Michael Berkman and ERIC PLUTZER \$85.00: Hb: 978-0-521-19046-6: $304 \mathrm{pp}$. \$27.99: Pb: 978-0-521-14886-3

Dismantling Democracy in Venezuela

The Chávez Authoritarian Experiment Allan Brewer-Carías \$115.00: Hb: 978-0-521-19587-4: $432 \mathrm{pp}$. \$39.99: Pb: 978-0-521-14557-2

Moral Movements and Foreign Policy JOSHUA W. BUSBY Cambridge Studies in International Relations \$85.00: Hb: 978-0-521-76872-6: $348 \mathrm{pp}$. \$29.99: Pb: 978-0-521-12566-6

Contemporary

Chinese Politics

New Sources, Methods, and Field Strategies

Edited by AlLEN CARLSON, Mary E. Gallagher,

KENNETH LIEBERTHAL, and Melanie Manion \$99.00: Hb: 978-0-521-19783-0: 336 pp. \$29.99: Pb: 978-0-521-15576-2
Imperial Sceptics

British Critics of Empire, 1850-1920

Gregory Claeys

\section{Ideas in Context}

\$95.00: Hb: 978-0-521-19954-4: 456 pp.

\section{The Diffusion of}

Social Movements

Actors, Mechanisms, and

Political Effects

Edited by

Rebecca Kolins Givan,

Kenneth M. Roberts,

and SARAH A. Soule

\$85.00: Hb: 978-0-521-19373-3: $272 \mathrm{pp}$. \$26.99: Pb: 978-0-521-13095-0

South Korea Since 1980

UK Heo and Terence Roehrig

The World Since 1980

\$85.00: Hb: 978-0-521-76116-1: 224 pp. \$27.99: Pb: 978-0-521-74353-2

The Transformation of the Workers' Party in Brazil, 1989-2009

Wendy Hunter

\$85.00: Hb: 978-0-521-51455-2: 256 pp. \$29.99: Pb: 978-0-521-73300-7

The Ironies of Citizenship Naturalization and Integration in Industrialized Countries

THOMAS JANOSKI

\$90.00: Hb: 978-0-521-76426-1: $352 \mathrm{pp}$ \$29.99: Pb: 978-0-521-14541-1

Morgenthau, Law and Realism

Oliver Jütersonke

\$85.00: Hb: 978-0-521-76928-0: $212 \mathrm{pp}$.

Why Nations Fight

Past and Future Motives for War

Richard Ned Lebow

\$99.00: Hb: 978-0-521-19283-5: 318 pp. \$29.99: Pb: 978-0-521-17045-1

The Ironic Defense

of Socrates

Plato's Apology

DAVID M. LeIBowitz

\$80.00: Hb: 978-0-521-19479-2: 204 pp.

\section{NEW SERIES!}

Competitive

Authoritarianism

Hybrid Regimes After the Cold War

SteVEn LeVITSKY

and LUCAN A. WAY

Problems of International Politics

\$95.00: Hb: 978-0-521-88252-1: 536 pp. \$29.99: Pb: 978-0-521-70915-6

The Sociology of

War and Violence

SINIŠA MALEŠEvić

\$95.00: Hb: 978-0-521-51651-8: 376 pp \$29.99: Pb: 978-0-521-73169-0

History and Neorealism

Edited by ERnest R. MAY,

RICHARD ROSECRANCE, and ZARA StEInER

\$99.00: Hb: 978-0-521-76134-5: 406 pp. \$33.99: Pb: 978-0-521-13224-4

Constituency Representation

in Congress

The View from Capitol Hill

Kristina C. Miler

\$85.00: Hb: 978-0-521-76540-4: 224 pp.

\section{TEXTBOOK}

The American Presidency An Analytical Approach

IRWIN L. MORRIS

\$90.00: Hb: 978-0-521-89592-7: 288 pp. \$44.00: Pb: 978-0-521-72043-4

Experimental Political Science and the Study of Causality From Nature to the Lab

Rebecca B. Morton and Kenneth C. Williams

\$110.00: Hb: 978-0-521-19966-7: 606 pp. \$39.99: Pb: 978-0-521-13648-8

Americanism in the

Twenty-First Century

Public Opinion in the

Age of Immigration

Deborah J. Schildkraut

\$85.00: Hb: 978-0-521-19175-3: 280 pp. \$26.99: Pb: 978-0-521-14524-4
Human Trafficking

A Global Perspective

LOUISE SHELLeY

\$85.00: Hb: 978-0-521-11381-6: 344 pp. \$26.99: Pb: $978-0-521-13087-5$

Global Financial Integration Thirty Years On

From Reform to Crisis

Edited by

GEOFFrEy R. D. UNDERHILL,

JASPER BLOM,

and Daniel Mügge

\$99.00: Hb: 978-0-521-19869-1: 374 pp.

Cultures of Power in Post-Communist Russia An Analysis of Elite Political Discourse

Michael URban

\$85.00: Hb: 978-0-521-19516-4: 228 pp.

\section{TEXTBOOK}

Challenges in Intelligence Analysis Lessons from 1300 BCE to the Present

Timothy Walton

\$90.00: Hb: 978-0-521-76441-4: 308 pp. \$32.99: Pb: 978-0-521-13265-7

John Locke and Modern Life LEE WARD

\$90.00: Hb: 978-0-521-19280-4: 328 pp.

The CDU and the Politics of Gender in Germany Bringing Women to the Party

Sarah Elise Wiliarty

\$85.00: Hb: 978-0-521-76582-4: $288 \mathrm{pp}$

Building Transnational Networks

Civil Society and the Politics of Trade in the Americas

Marisa von Bülow

Cambridge Studies in

Contentious Politics

\$80.00: Hb: 978-0-521-19156-2: 280 pp.

\section{www.cambridge.org/us 800.872 .7423}

